Article

\title{
Detoxification of Cylindrospermopsin by Pyrite in Water
}

\author{
Shulian Wang $1, *\left(\mathbb{D}\right.$, Yongmei Chen ${ }^{2}$, Yiying Jiao ${ }^{1}$ and $\mathrm{Zhu} \mathrm{Li}^{1}$ \\ 1 Hubei Key Laboratory of Ecological Remediation for Rivers-Lakes and Algal Utilization, School of Civil \\ Engineering, Architecture and Environment, Hubei University of Technology, Wuhan 430068, China \\ 2 Wuhan Vocational College of Software Engineering, Wuhan Radio \& TV University, Wuhan 430205, China \\ * Correspondence: wangshulian@hbut.edu.cn; Tel.: +86-130-0610-5245
}

Received: 30 July 2019; Accepted: 18 August 2019; Published: 21 August 2019

check for updates

\begin{abstract}
Cylindrospermopsin (CYN) is a cyanobacterial toxin released from eutrophic water. It persistently remains in the environment because its degradation under solar light is extremely low. In this study, pyrite, an abundant mineral, was investigated as a catalyst for decomposing and detoxifying CYN in water. A detailed examination of intermediates provided insights into the degradation pathway. Electron spin resonance spectra revealed that $\mathrm{H}_{2} \mathrm{O}_{2}$ and hydroxyl radicals $(\bullet \mathrm{OH})$ were generated at the pyrite surface while promoting the recycling of Fe(III) into Fe(II) during the degradation process. This degradation system could be uniquely efficient in the presence of relatively high levels of natural organic matter because the structure of the uracil ring is decomposed to detoxify CYN. This work confirms a new approach to selectively and effectively detoxifying CYN in water using an inexpensive, environmentally friendly, and bio-compatible mineral.
\end{abstract}

Keywords: pyrite; cylindrospermopsin (CYN); degradation; detoxification

\section{Introduction}

In recent years, cylindrospermopsin $(\mathrm{CYN})$, detected in eutrophic water bodies of many countries across the world, has attracted increasing attention [1]. CYN is a guanidine alkaloid which contains three-ring guanidine and hydroxymethyl uracil (Figure 1). It is highly stable when exposed to different $\mathrm{pH}$ and temperature conditions, and thus it accumulates easily in organisms and is highly toxic [2]. The toxic mechanism of CYN is to participate in various enzyme reactions by competing with the binding sites of uridine diphosphate (UDP) because the uracil group in the CYN structure is similar to the guanosine structure in uridine diphosphate [3]. At the extremely low concentration of $10^{-7} \mu \mathrm{g} / \mathrm{L}$, CYN has a potential carcinogenic risk [4]. In eutrophic water, the degradation efficiency of CYN under natural conditions is low and mainly depends on the irradiation of UV-A. CYN belongs to refractory and refractory biological toxins [5]. Therefore, once CYN is produced in a water body, it will exist stably and pose a great threat to the water ecological environment and human health.<smiles>CC1C(OS(=O)(=O)O)CC2CC(C(O)c3cc(=O)[nH]c(=O)[nH]3)N=C3NCC1N32</smiles>

Figure 1. The structure of cylindrospermopsin (CYN). 
Hydroxyl radical $(\bullet \mathrm{OH})$ is an active species with high oxidation potential $\left(E_{0}=2.76 \mathrm{~V}\right)$; thus, its oxidation activity is strong, and its effect on the transformation of harmful substances in the natural environment is important [6]. Song et al. reported the detoxification of $\mathrm{CYN}$ in water by ${ }^{\bullet} \mathrm{OH}$ produced by gamma ray irradiation for the first time. The degradation and detoxification mechanism of $\mathrm{CYN}$ is due to the reaction of ${ }^{\bullet} \mathrm{OH}$ with the toxic group of uracil in $\mathrm{CYN}$, which can be converted into carboxyl via addition and oxidation reactions [7]. Although this method exhibits a certain detoxification effect, it is costly. Hence, an economical and effective treatment method to generate ${ }^{\bullet} \mathrm{OH}$ is urgently needed. McNeill reported that the reductive organic matter in surface water could react with $\mathrm{O}_{2}$ to produce • $\mathrm{OH}$ [8]. Furthermore, Yuan et al. found that the production amount of ${ }^{\bullet} \mathrm{OH}$ in the oxidation process of underground sediments is positively correlated with that of solid-phase $\mathrm{Fe}(\mathrm{II})$, which they proved to be the leading factor in the formation of ${ }^{\bullet} \mathrm{OH}$ [9]. This discovery reveals that solid sediments in the underground environment make up a large ${ }^{\bullet} \mathrm{OH}$ reservoir that has been generally neglected.

Pyrite is abundant in underground sediments and is widely distributed in the underground strata of rivers. Although pyrite is formed in an anoxic environment, it remains stable in an aerobic environment [10]. Pyrite has an important effect on the migration, transformation, and degradation of toxic and harmful substances. Fe(II) in pyrite exists in the form of a bound state, which can enhance the reductive activity and accelerate the oxidation rate of $\mathrm{Fe}(\mathrm{II})$ to produce ${ }^{\bullet} \mathrm{OH}$. These studies show that pyrite can produce reactive oxygen species (ROS) to degrade CYN in a short time, similar to other advanced oxidation processes (AOPs). However, one of the biggest drawbacks of most AOPs is the lack of selectivity. At present, almost all AOPs regarding CYN degradation dissolve CYN in pure water without considering the coexistence of natural organic matter (NOM). Thus, a great amount of - $\mathrm{OH}$ is preferable to react with a high concentration of NOM than a trace quantity of CYN. Therefore, AOPs are still difficult to use in real scenarios. This poses a challenge, because $\mathrm{CYN}$ generally occurs at low concentrations ( $<10 \mathrm{ppm}$ ), while the concentration of NOM is commonly in the range from 10 to $100 \mathrm{ppm}$ [11]. Because of the inefficiency of CYN degradation by these processes, environmentally friendly methods for CYN removal in the presence of NOM are important.

In the work reported here, pyrite was used as a visible light catalyst to degrade CYN in water at neutral $\mathrm{pH}$ using dissolved oxygen as the initial oxidant. The cleavage of the stable uracil ring structure facilitated oxidative decomposition. The ${ }^{\bullet} \mathrm{OH}$ formation was monitored using electron spin resonance (ESR), and the unique degradation products of CYN were identified by liquid chromatography-mass spectroscopy (LC/MS). The pyrite catalytic system reported in this paper introduces a promising new approach to effectively and selectively detoxifying CYN in water treatments with high levels of NOM.

\section{Results and Discussion}

\subsection{Degradation of $\mathrm{CYN}$}

The degradation kinetics of CYN in aqueous solution with pyrite and the comparative experiment without pyrite are displayed in Figure 2a. Plotting $\ln \left(c_{t} / c_{0}\right)$ against reaction time $(t)$ presented a straight line (Figure $2 b$ ). Thus, the degradation kinetics of $\mathrm{CYN}$ by pyrite were treated as a pseudo-first order.

$$
\begin{aligned}
& \ln \frac{c_{t}}{c_{0}}=k t \\
& t_{\frac{1}{2}}=\frac{\ln 2}{k}
\end{aligned}
$$

where $c_{0}$ and $c_{t}$ are the concentrations of CYN at time zero and time $t$, respectively. 

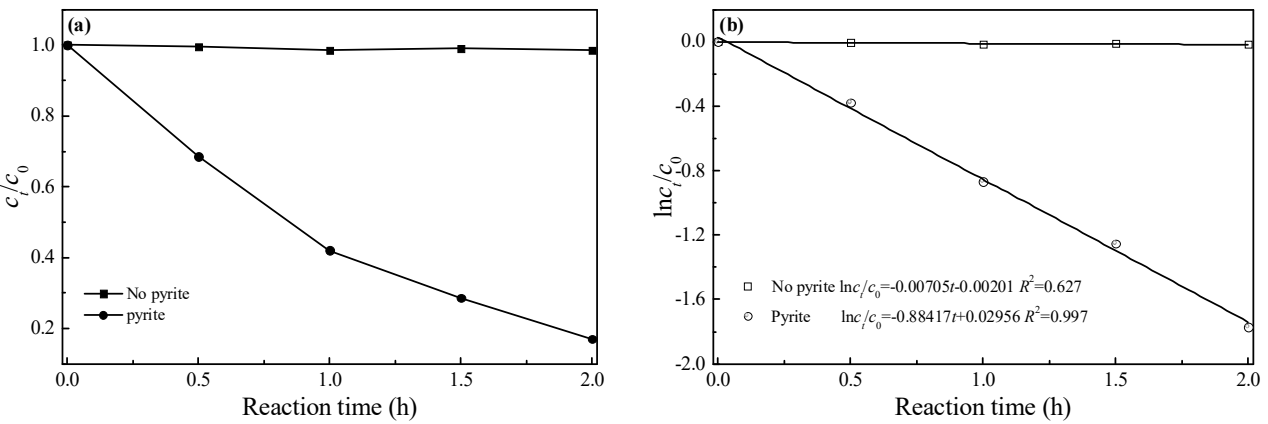

Figure 2. (a) Reactions of pyrite catalyzed detoxification of CYN and control. (b) Reaction kinetics of CYN detoxification, assuming pseudo-first order kinetics. CYN concentration $=2 \mathrm{mg} / \mathrm{L}$; pyrite dose $=0.5 \mathrm{~g} / \mathrm{L}$; no $\mathrm{pH}$ adjustment.

In the reaction, the concentration of CYN at a given reaction time can be calculated using Equation (1). When the log of CYN concentration is plotted as a function of time, the rate constant $(k)$ is given by the slope, and the CYN half-life can be calculated using Equation (2). For the degradation system in the presence and absence of pyrite, the rate constants were 0.8842 and $0.0071 \mathrm{~h}^{-1}$, and the half-lives were 0.78 and $98 \mathrm{~h}$, respectively. Consequently, the presence of pyrite reduced the half-life of CYN in water by $99 \%$, similar to the degradation systems of microcystin-LR (MC-LR) by kaolinite and siderite [12].

The recycling of pyrite was examined for the degradation of CYN over five consecutive cycles. After each cycle experiment, the solution residue was filtered. Pyrite powder was rinsed and dried, and used again for the degradation of CYN with identical experimental conditions. Pyrite displayed a high degradation activity after five cycles of recovery and reuse (Figure 3). Humic acid (HA), a common and often dominant component of NOM in natural waters, was added to the CYN solution to compare the effectivity of pyrite toward CYN degradation in the presence of NOM. The results indicated that pyrite successfully degrades CYN in water even if the concentration of HA exceeds that of CYN by a factor of 10. In addition, the concentration of Fe in degradation solution was determined at the end of each degradation cycle. The results showed that the loss of Fe was only $0.35 \%$ at the first cycle and reached $3.27 \%$ after five continuous cycles (Figure 3). From other research, the maximum content of Fe in solution during the degradation of trichloroethylene by pyrite was found to be $0.082 \mathrm{mM}(\mathrm{pH}=3)$, which only accounted for $0.46 \%$ of Fe in pyrite [13]; Fe detected in the solution after $6 \mathrm{~h}$ reaction was only $0.05 \mathrm{mM}(\mathrm{pH}=7)$ when pyrite was used to degrade chloroaniline [14]. It is obvious that the Fe leaching is inevitable, but the amount is low.

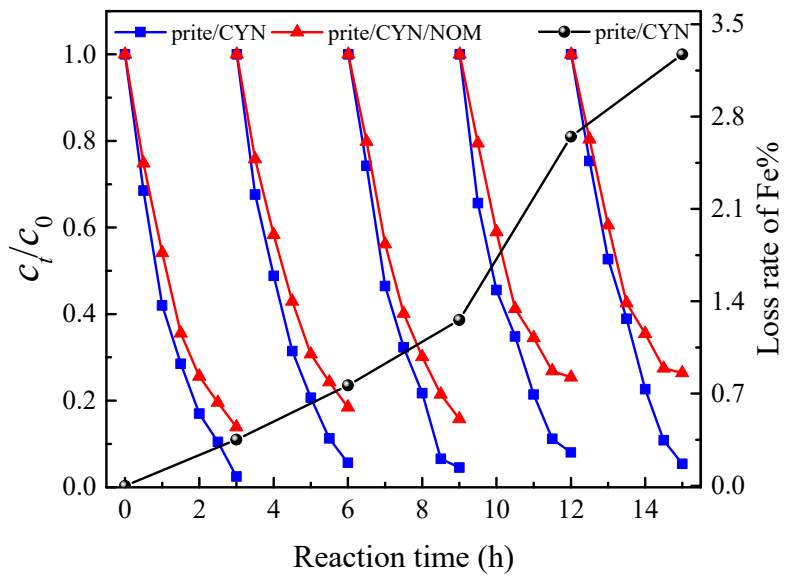

Figure 3. Results of recycling degradation. CYN concentration $=2 \mathrm{mg} / \mathrm{L} ;$ humic acid (HA) concentration $=20 \mathrm{mg} / \mathrm{L}$; pyrite dose $=0.5 \mathrm{~g} / \mathrm{L}$; no $\mathrm{pH}$ adjustment . 


\subsection{Formation of Active Species}

To clarify the important role of pyrite in the degradation of CYN, ESR with spin-trapping 5, 5-dimethyl-1-pyrroline $\mathrm{N}$-oxide (DMPO) was used to observe the production of ${ }^{\bullet} \mathrm{OH}$ free radicals during the degradation process. The formation of radicals during degradation was qualitatively proved by ESR using the non-saturated anti-magnetic material DMPO as the spin trapping agent to detect and identify short-lived free radicals (Figure 4). The DMPO- ${ }^{\circ} \mathrm{OH}$ adduct is a signal with an intensity ratio of 1:2:2:1, and its presence is a clear indication of ${ }^{\bullet} \mathrm{OH}$ formation.

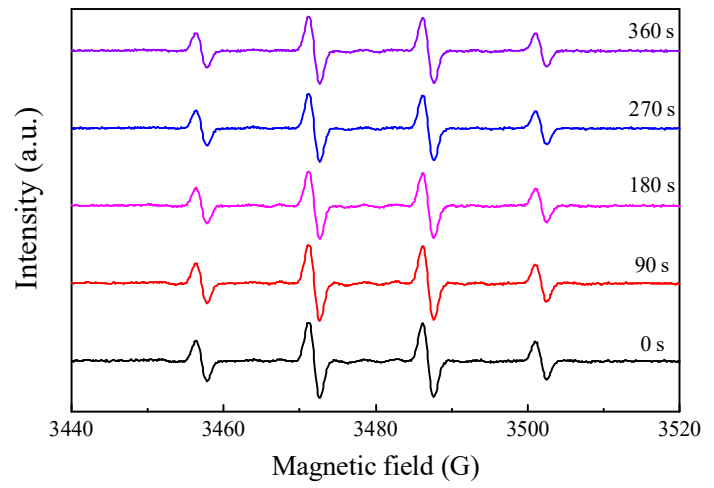

Figure 4. Electron spin resonance (ESR) signals of the 5, 5-dimethyl-1-pyrroline $N$-oxide (DMPO)- ${ }^{\bullet} \mathrm{OH}$ adducts in aqueous solution under visible light irradiation in the system of pyrite and CYN. DMPO concentration $=0.04 \mathrm{~mol} / \mathrm{L}$; pyrite dose $=0.5 \mathrm{~g} / \mathrm{L}$.

Degradation obviously occurs under open conditions, and thus dissolved $\mathrm{O}_{2}$ in water may play a crucial role $[10,15,16]$. In this study, $\mathrm{CYN}$ degradation under $\mathrm{N}_{2}$ (to remove completely dissolved $\mathrm{O}_{2}$ ) was implemented to further verify the role of $\mathrm{O}_{2}$. The result showed (Figure $5 \mathrm{a}$ ) that only $17.6 \%$ of CYN was degraded; hence, $\mathrm{O}_{2}$ reduction was the main mechanism for the formation of ${ }^{\bullet} \mathrm{OH}$ at the pyrite surface. Moreover, quenching experiments using tert-butyl alcohol (TBA) as an ${ }^{\bullet} \mathrm{OH}$ scavenger indicated that no degradation occurred (Figure 5a). Thus, the reactivity coupled with iron delivery provides bright prospects in the degradation of CYN and other toxic substances in wastewater.
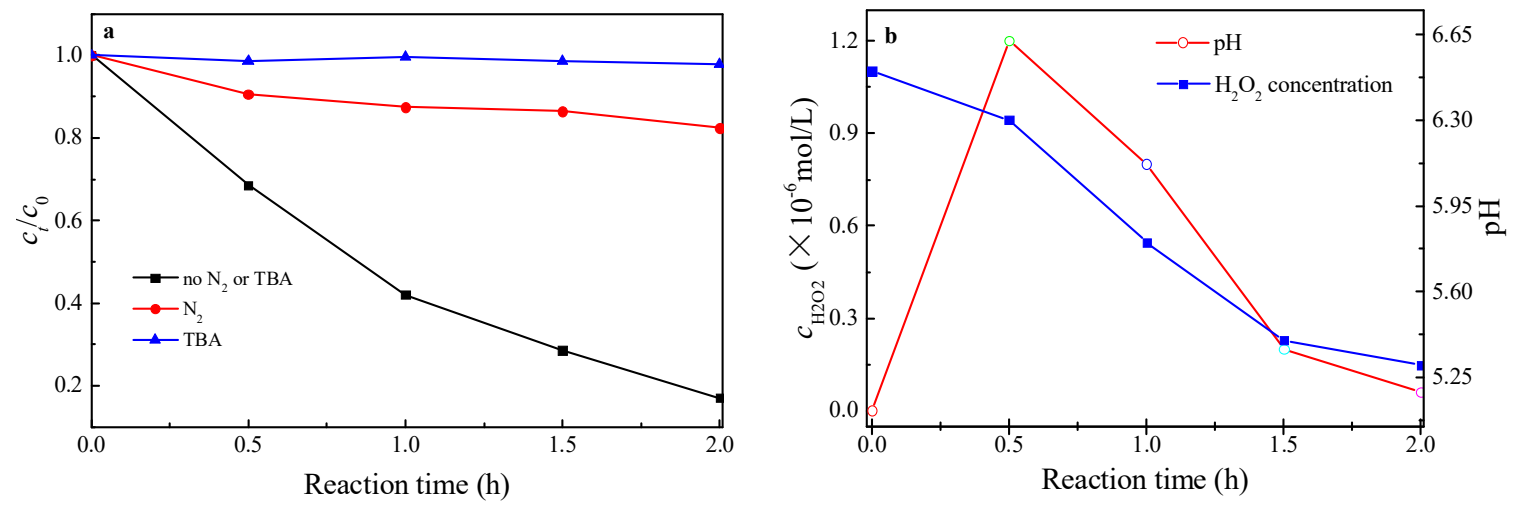

Figure 5. (a) Degradation of CYN under different conditions; (b) $\mathrm{pH}$ and $\mathrm{H}_{2} \mathrm{O}_{2}$ evolution in the degradation solution. $\mathrm{CYN}$ concentration $=2 \mathrm{mg} / \mathrm{L}$; tert-butyl alcohol (TBA) concentration $=2 \mu \mathrm{L} / \mathrm{mL}$; pyrite dose $=0.5 \mathrm{~g} / \mathrm{L}$.

At the pyrite surface, iron defect sites, which easily adsorb $\mathrm{O}_{2}$ and water to form a surface complex, are found. The complex transfers an electron to generate $\mathrm{O}_{2}{ }^{--}$(Equation (3)) and continues to transfer another electron to generate $\mathrm{H}_{2} \mathrm{O}_{2}$ ads (Equation (4)). Then, a Haber-Weiss reaction occurs to generate ${ }^{\bullet} \mathrm{OH}$. 


$$
\begin{gathered}
\mathrm{Fe}(\mathrm{II})+\mathrm{O}_{2} \text { ads } \\
\rightarrow \mathrm{Fe}(\mathrm{III})+\mathrm{O}_{2}^{\bullet-} \\
\mathrm{Fe}(\mathrm{II})+2 \mathrm{O}_{2}^{\bullet-}+2 \mathrm{H}^{+} \rightarrow \mathrm{Fe}(\mathrm{III})+\mathrm{H}_{2} \mathrm{O}_{2 \text { ads }}
\end{gathered}
$$

During this whole process, $\mathrm{H}_{2} \mathrm{O}_{2}$ ads, which plays an important role in CYN degradation, is detected (Figure $5 b$ ). A portion of $\mathrm{H}_{2} \mathrm{O}_{2}$ ads is reduced by the pyrite to $\mathrm{H}_{2} \mathrm{O}$, and the other portion is desorbed into the solution. For the dissolved $\mathrm{H}_{2} \mathrm{O}_{2}$, only a fraction is consumed by the oxidizing pyrite while the remaining fraction reacts with $\mathrm{Fe}(\mathrm{II})$ through the Fenton mechanism to generate ${ }^{\bullet} \mathrm{OH}$ (Equation (5)).

$$
\mathrm{Fe}(\mathrm{II})+\mathrm{H}_{2} \mathrm{O}_{2 \mathrm{ads}} \rightarrow \mathrm{Fe}(\mathrm{II})+\mathrm{HO}^{-}+{ }^{\bullet} \mathrm{OH}
$$

At this moment, $\mathrm{Fe}(\mathrm{II})$ begins to catalyze the decomposition of $\mathrm{H}_{2} \mathrm{O}_{2}$ into ${ }^{\bullet} \mathrm{OH}$. Simultaneously, the amount of $\mathrm{Fe}(\mathrm{II})$ required for the Fenton reaction to occur is supplied to the solution by the oxidative dissolution of pyrite in the presence of $\mathrm{O}_{2}$ aq (Equation (6)).

$$
2 \mathrm{FeS}_{2}+7 \mathrm{O}_{2 \mathrm{aq}}+2 \mathrm{H}_{2} \mathrm{O} \rightarrow 2 \mathrm{Fe}(\mathrm{II})+4 \mathrm{SO}_{4}^{2-}+4 \mathrm{H}^{+}
$$

The regeneration of Fe(II) may occur according to an additional mechanism (Equation (7)).

$$
\mathrm{FeS}_{2}+8 \mathrm{H}_{2} \mathrm{O}+14 \mathrm{Fe}(\mathrm{III}) \rightarrow 15 \mathrm{Fe}(\mathrm{II})+2 \mathrm{SO}_{4}^{2-}+16 \mathrm{H}^{+}
$$

Equations (6) and (7) release protons to promote acidification and deliver Fe (II) into the degradation solution. In the performed experiments, the release and use of protons causes fluctuation in $\mathrm{pH}$, and the $\mathrm{pH}$ usually attained a final value of 5-6.5 (Figure 5b) with a highly efficient Fenton chain reaction.

\subsection{Proposed Degradation Pathway}

The structures for the degradation products of CYN were proposed on the basis of the analysis of the total ion chromatograms (TICs), which are summarized in Table 1. The LC/MS analysis of the decomposition fragments revealed at least four intermediates, each producing strong peaks in the TIC. Most intermediates were initially abundant and gradually decreased with the extending reaction time. In the structure of $C Y N$, the double bond of the electron-rich unsaturated uracil ring was easily added by ${ }^{\bullet} \mathrm{OH}$ to yield products such as $\mathrm{m} / \mathrm{z} 413$ and $\mathrm{m} / \mathrm{z} 447$. Product $\mathrm{m} / \mathrm{z} 447$ was observed as a secondary dihydroxylation product. The hydrogen abstraction reaction of the hydroxyl group occurred to generate $\mathrm{m} / \mathrm{z} 413$. Moreover, product $\mathrm{m} / \mathrm{z} 319$ resulted from the breakage of the uracil ring. The detoxification pathway was proposed by combining the results of ESR and LC/MS (Figure 6). The detoxification of $\mathrm{CYN}$ occurred through the breakage of uracil moiety by the ${ }^{\bullet} \mathrm{OH}$ generated in the system [17].

Table 1. Intensity of LC/MS peak area $\left(\right.$ count $\times 10^{5}$ ) for intermediates produced during CYN degradation by pyrite ${ }^{\text {a }}$.

\begin{tabular}{cccccc}
\hline $\begin{array}{c}\text { Reaction } \\
\text { Time }(\mathbf{h})\end{array}$ & $\begin{array}{c}\text { CYN } \\
(\mathrm{m} / \boldsymbol{z} \text { 415.6) }\end{array}$ & $\begin{array}{c}\text { Product 1 } \\
(\mathrm{m} / \boldsymbol{z} \text { 431.4) }\end{array}$ & $\begin{array}{c}\text { Product 2 } \\
(\mathrm{m} / \boldsymbol{z} \text { 447.3) }\end{array}$ & $\begin{array}{c}\text { Product 3 } \\
(\mathrm{m} / \boldsymbol{z} \text { 413.4 })\end{array}$ & $\begin{array}{c}\text { Product 4 } \\
(\mathrm{m} / \boldsymbol{z} \text { 319.3) }\end{array}$ \\
\hline 0 & 5.28 & 0 & 0 & 0 & 0 \\
1.5 & 3.73 & 0.17 & 0.64 & 0.19 & 0.18 \\
2 & 2.26 & 0.24 & 1.76 & 0.26 & 0.31 \\
2.5 & 1.06 & 0.16 & 1.59 & 0.41 & 0.45 \\
3 & 0.25 & 0.12 & 0.29 & 0.13 & 0.28 \\
\hline
\end{tabular}

\footnotetext{
a Solution volume $=5 \mathrm{~mL} ; \mathrm{CYN}$ concentration $=2 \mathrm{mg} / \mathrm{L} ;$ pyrite dose $=0.5 \mathrm{~g} / \mathrm{L} ;$ no $\mathrm{pH}$ adjustment. The retention time of
} CYN and product $1,2,3$ and 4 are $9.1,7.6,7.1,10.9$ and $5.6 \mathrm{~min}$, respectively. 


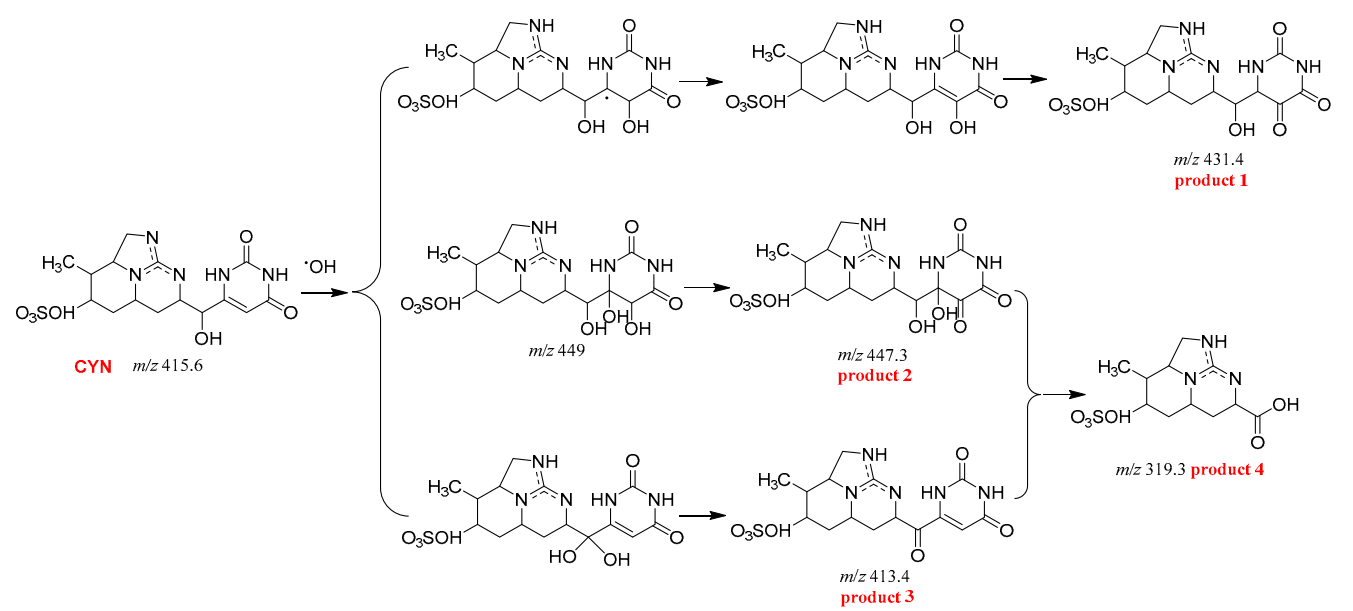

Figure 6. Proposed detoxification pathways of CYN by pyrite.

\subsection{Effects of Degradation Products on Toxicity}

The deep mineralization of pollutants to carbon dioxide, water, and other inorganic salts is the best detoxification method. However, completely realizing mineralization for organic pollutants with complex structures, such as CYN, is difficult. In this system with pyrite, the total organic carbon (TOC) removal rate was only $47 \%$ after $2 \mathrm{~h}$ of visible light irradiation (Figure S1). Thus, the removal of toxic groups is effective for the detoxification of CYN. An acute toxicity study was performed on mice to measure the detoxification extent of CYN by pyrite. Group 1 was the control, and group 2 received original CYN (2 mg/L) with a dose of $10 \mathrm{~mL} / \mathrm{kg}$. Groups 3, 4, and 5 were given 10, 20, and $30 \mathrm{~mL} / \mathrm{kg}$ of degradation solution after $5 \mathrm{~h}$, respectively. All mice in group 2 died within $12 \mathrm{~h}$, and necropsies were performed to observe their livers and weight. All mice in the four other groups survived for 14 days but were killed for examination. The results (Figure 7) revealed that the livers of mice in group 2 were severely swollen and discolored, and the liver index increased $(p<0.05)$. However, the livers of the mice in the three other experimental groups were normal, and the liver indexes of groups $3(p<0.01)$, $4(p<0.05)$, and $5(p<0.05)$ were similar to that of the control group. These results clearly show that degradation by pyrite remarkably reduces the acute toxicity of CYN.

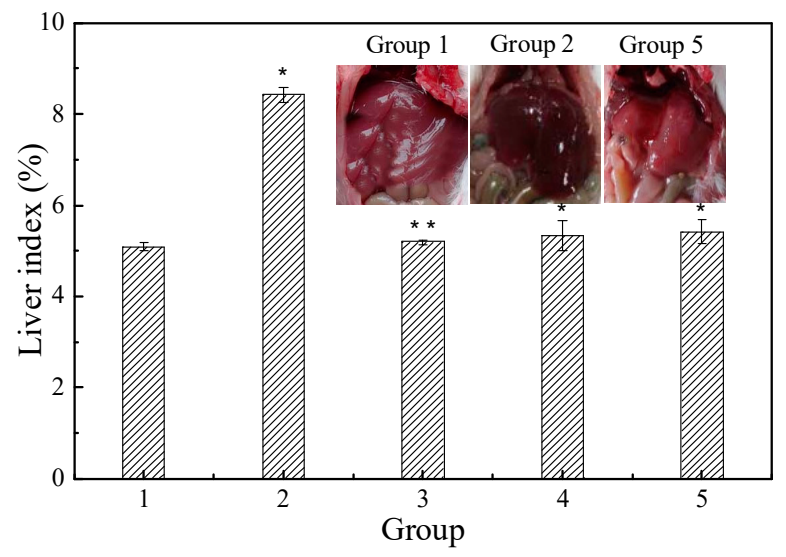

Figure 7. Liver index of Kunming mice (KM) mice under toxic experiment $(n=10)$. Asterisk denotes a response that is significantly different from the control $\left({ }^{*} p<0.05,{ }^{* *} p<0.01\right)$.

\section{Materials and Methods}

\subsection{Reagents}

CYN standard ( $25 \mu \mathrm{g}$ solid, purity $\geq 95 \%$ by HPLC) was purchased from Express Technology Co., Ltd. and stored at $-25^{\circ} \mathrm{C}$. CYN stock solution was prepared by adding water to dissolve the CYN 
standard and then stored at $4{ }^{\circ} \mathrm{C}$. DMPO ( $\geq 98.0 \%$ GC) for ESR-spectroscopy and technical-grade HA (ign. residue 20\%) were obtained from Sigma-Aldrich Co. (St. Louis, MO, USA) Chromatographic grade methanol and acetonitrile were obtained from Merck Co. (Kenilworth, NJ, USA) All reagents were used without further purification. Deionized and doubly distilled water were used throughout this study. Other chemicals were of analytical reagent grade.

Pyrite $\left(\mathrm{FeS}_{2}\right)$ samples were provided by the Central-South Research Institute of Metallurgical Geology (Hubei, China). Pyrite was washed to remove natural contaminants, and ground and sieved (100 mesh) to obtain crystal particles $(\leq 150 \mu \mathrm{m})$. The molecular formula of $\mathrm{FeS}_{2}$ was $\mathrm{Fe}_{1.024} \mathrm{~S}_{1.975} \mathrm{Ca}_{0.001}$ from an electron probe micro-analyzer (EPMA)(JXA-8230, JEOL, Akishima, Japan). The crystalline phases of pyrite were characterized by Ultima IV X-ray diffractometry (Rigaku, Japan) with Cu $K_{\alpha}$ radiation $\left(\lambda=1.54178 \AA\right.$ ) and a scan rate of $2.4^{\circ} / \mathrm{min}$ from $20^{\circ}$ to $80^{\circ}$. The results (Figure S2) revealed the typical pyrite structure of the isometric system with unit cell parameters $a=b=c=5.418 \AA(z=4)$. The Fe atom occupied the corner top and center of the cube cell. At the same time, the $S$ atom consisted of the dumbbell-shaped sulfur $\left[\mathrm{S}_{2}\right]^{2-}$, and the center was located at the center of the crystal cell and body center. The valence state of the metal elements provided them with good catalytic activity. The characteristic peaks of the primary components were designated with asterisks $(*)$, and they compared well with the reference material (JCPDS 42-1340). The specific surface area was $1.12 \mathrm{~m}^{2} / \mathrm{g}$, which was determined by using a BELSORP-mini II BET instrument (MicrotracBEL, Osaka, Japan). $\mathrm{pH}_{\text {PZC was }}$ 6.4, which was detected by using a Zetasizer Nano Zeta potentiometer (Malvern, UK).

\subsection{Photocatalytic Process}

Degradation reactions were carried out in $10 \mathrm{~mL}$ brown reaction vessels. Exactly $5 \mathrm{~mL}$ of $2.0 \mathrm{mg} / \mathrm{L}$ $\mathrm{CYN}$ and $2.5 \mathrm{mg}$ of pyrite powder (optimum dosage under experimental conditions shown in Figure S3) were placed in the reaction vessel. The solution $\mathrm{pH}$ was not adjusted, and the $\mathrm{pH}$ of the suspensions was measured to $6.5 \pm 0.2$. The light source was a $500 \mathrm{~W}$ halogen lamp (Institute of Electric Light Source, Beijing, China) positioned in an XPA series photochemical reaction instrument. A cut-off filter (diameter of $3 \mathrm{~cm}$ ) was placed outside the Pyrex jacket to eliminate any radiation at a wavelength below $420 \mathrm{~nm}$ and to ensure illumination by visible light only. The distance between the reaction vessel and the light source was $10 \mathrm{~cm}$. Prior to degradation, the suspensions were magnetically stirred in the dark for $2 \mathrm{~h}$ to ensure that adsorption/desorption equilibrium was established. At specific time intervals, $300 \mu \mathrm{L}$ aliquots of the reaction mixture were collected, centrifuged, and then filtered through a Millipore filter (pore size of $0.22 \mu \mathrm{m}$ ) to remove the solid particles prior to the analysis using the methods described below. The selective degradation of pyrite toward CYN in the presence of NOM was tested using HA, which is a complex mixture of different acids that contain carboxyl and phenolic groups and is the major NOM in many natural waters [11,18,19]; thus, it is usually used as a model NOM.

\subsection{Analytical Methods}

CYN was determined using HPLC (Agilent 1200, Santa Clara, CA, USA) with a UV detector and a C18 reverse-phase column $(5 \mu \mathrm{m} ; 4.6 \mathrm{~mm}$ i.d. $\times 250 \mathrm{~mm}$, Kromasil). Gradient elution for the determination of CYN began from $2 \%$ methanol and $98 \%$ water, followed by a linear increase of methanol to reach $20 \%$ at $10 \mathrm{~min}$. The injection volume was $20 \mu \mathrm{L}$. The flow rate was $0.40 \mathrm{~mL} / \mathrm{min}$, and the detection wavelength was $262 \mathrm{~nm}$. Under these conditions, the elution time for CYN was approximately $6.6 \mathrm{~min}$ (Figure S4).

Hydroxyl radical levels were tested by EPR 300E spectrometer (Bruker, Germany) equipped with a Quanta-Ray Nd:YAG laser (355 and $532 \mathrm{~nm}$ ) for the measurement of the ESR signals of - OH spin-trapped 5, 5-dimethyl-1-pyrroline $\mathrm{N}$-oxide (DMPO). Measurement conditions were as follows: center field, $3486.7 \mathrm{G}$; sweep width, $100 \mathrm{G}$; microwave frequency, $9.82 \mathrm{GHz}$; and power, $5.05 \mathrm{~mW}$. The same quartz capillary tube was used for all ESR measurements to minimize experimental 
errors. The concentration variations of $\mathrm{H}_{2} \mathrm{O}_{2}$ during the photodegradation were determined by the $\mathrm{N}$, $\mathrm{N}$-diethyl-p-phenylenediamine method [20].

Reaction intermediates were monitored using a liquid chromatography tandem mass spectrometry (LC/MS) instrument (Agilent 1200 LC/6420 ion trap MS, Santa Clara, CA, USA) with an electrospray ionization interface by full scanning from $m / z 50$ to 600 in the positive ion mode.

The acute toxicity testing of CYN degradation products was evaluated by the maximum tolerance method. Kunming mice (KM) (16-20 g, 50 males and 50 females) were used in the study. All mice were randomly and equally assigned to five groups (one control group and four experimental groups) and housed in an animal holding room, which was kept at $20-25{ }^{\circ} \mathrm{C}$ and $40-60 \%$ relative humidity with a regime of a $12 \mathrm{~h}$ light/dark cycle. These mice were fasted for $12 \mathrm{~h}$ before the experiment but had no restriction of drinking water. Within $24 \mathrm{~h}$, treated $(5 \mathrm{~h}) \mathrm{CYN}$ solutions were administered by i.g. injection at doses of 10,20 , and $30 \mathrm{~mL} / \mathrm{kg}$ body weight. Distilled water with equal volume was injected into the mice in the control group. All mice were released from fasting after being injected. After $48 \mathrm{~h}$, the animals were observed closely. The body weight, appearance, and diet of these mice were recorded daily throughout the 14-day test period. After 15 days of administration, the mice were anesthetized with $1 \%$ pentobarbital sodium to weigh their bodies and livers to calculate liver index (liver weight/body weight, \%).

\section{Conclusions}

Pyrite was employed to decompose CYN, whose half-life was reduced by $99 \%$. During the degradation of CYN, pyrite was reusable and Fe leaching was scare after five continuous cycles. It was remarkable that the degradation of CYN by pyrite was not affected by NOM, even if the concentration of HA exceeded that of CYN by a factor of 10 . The degradation is attributed to the oxidation of ${ }^{\bullet} \mathrm{OH}$ generated from oxygen reduction to remove the uracil moiety, which is the toxic unit of CYN. Even though the TOC removal rate of CYN was only $47 \%$ after $2 \mathrm{~h}$ of visible light irradiation, the degradation products were non-toxic. In summary, pyrite has promising application prospects in predominantly detoxifying CYN in the presence of NOM because pyrite targets the uracil ring. This study indicates that pyrite is an efficient means for the remediation of natural water polluted by CYN and gives new insights into the reactivity of pyrite toward environmental contaminants.

Supplementary Materials: The following are available online at http://www.mdpi.com/2073-4344/9/9/699/s1, Figure S1: Determination of TOC during CYN degradation. CYN concentration $=2 \mathrm{mg} / \mathrm{L} ;$ pyrite dose $=0.5 \mathrm{~g} / \mathrm{L}$, Figure S2: XRD pattern of pyrite. The positions and intensities of the diffraction lines of pyrite (JCPDS 42-1340) are indicated by marks just above the horizontal axis, Figure S3: Effect of pyrite dosage on the degradation effect of CYN. CYN concentration $=2 \mathrm{mg} / \mathrm{L}$, Figure S4: Concentration change of CYN before $(0 \mathrm{~h})$ and after (2 h) degradation.

Author Contributions: Data curation, Y.J., Z.L.; Formal analysis, Y.C.; Funding acquisition, S.W.; Investigation, Y.J;; Methodology, Y.C.; Supervision, S.W.; Writing—original draft, S.W.; Writing—review \& editing, S.W.

Funding: This work was funded by the National Natural Science Foundation of China (No. 51909082), the Natural Science Foundation of Hubei Province (No. 2016CFB190), Open Fund of Key Laboratory (No. HHKF201510) and Wuhan Science and Technology Project (No. 2015061701011615).

Conflicts of Interest: The authors declare no conflict of interest.

\section{References}

1. Gaget, V.; Humpage, A.R.; Huang, Q.; Monis, P.; Brookes, J.D. Benthic cyanobacteria: A source of cylindrospermopsin and microcystin in Australian drinking water reservoirs. Water Res. 2017, 124, 454-464. [CrossRef] [PubMed]

2. López-Alonso, H.; Rubiolo, J.A.; Vega, F.; Vieytes, M.R.; Botana, L.M. Protein synthesis inhibition and oxidative stress induced by cylindrospermopsin elicit apoptosis in primary rat hepatocytes. Chem. Res. Toxicol. 2013, 26, 203-212. [CrossRef] [PubMed] 
3. Banker, R.; Carmeli, S.; Werman, M.; Teltsch, B.; Porat, R.; Sukenik, A. Uracil moiety is required for toxicity of the cyanobacterial hepatotoxin cylindrospermopsin. Toxicol. Environ. Health 2001, 62, 281-288. [CrossRef] [PubMed]

4. Maire, M.A.; Bazin, E.; Fessard, V.; Rast, C.; Humpage, A.R.; Vasseur, P. Morphological cell transformation of Syrian hamster embryo (SHE) cells by the cyanotoxin, cylindrospermopsin. Toxicon 2010, 55, 1317-1322. [CrossRef] [PubMed]

5. Wörmer, L.; Huerta-Fontela, M.; Cirés, S.; Carrasco, D.; Quesada, A. Natural photodegradation of the cyanobacterial toxins microcystin and cylindrospermopsin. Environ. Sci. Technol. 2010, 44, 3002-3007. [CrossRef] [PubMed]

6. Zhao, C.; Pelaez, M.; Dionysiou, D.D.; Pillai, S.C.; Byrne, J.A.; O'Shea, K.E. UV and visible light activated TiO photocatalysis of 6-hydroxymethyl uracil, a model compound for the potent cyanotoxin cylindrospermopsin. Catal. Today 2014, 224, 70-76. [CrossRef]

7. Song, W.; Yan, S.; Cooper, W.J.; Dionysiou, D.D.; O'Shea, K.E. Hydroxyl radical oxidation of cylindrospermopsin (cyanobacterial toxin) and its role in the photochemical transformation. Environ. Sci. Technol. 2012, 46, 12608-12615. [CrossRef] [PubMed]

8. Page, S.E.; Kling, G.W.; Sander, M.; Harrold, K.H.; Logan, J.R.; McNeill, K.; Cory, R.M. Dark formation of hydroxyl radicals in arctic soil and surface waters. Environ. Sci. Technol. 2013, 47, 12860-12867. [CrossRef] [PubMed]

9. Tong, M.; Yuan, S.; Ma, S.; Jin, M.; Liu, D.; Cheng, D.; Liu, X.; Gan, Y.; Wang, Y. Production of abundant hydroxyl radicals from oxygenation of subsurface sediments. Environ. Sci. Technol. 2016, 50, $214-221$. [CrossRef] [PubMed]

10. Zhang, P.; Yuan, S.; Liao, P. Mechanisms of hydroxyl radical production from abiotic oxidation of pyrite under acidic conditions. Geochim. Cosmochim. Acta 2016, 172, 444-457. [CrossRef]

11. Aschermann, G.; Jeihanipour, A.; Shen, J.; Mkongo, G.; Dramas, L.; Croue, J.P.; SchaFer, A. Seasonal variation of organic matter concentration and characteristics in the Maji ya Chai River (Tanzania): Impact on treatability by ultrafiltration. Water Res. 2016, 101, 370-381. [CrossRef] [PubMed]

12. Fang, Y.; Zhou, W.; Tang, C.; Huang, Y.; Johnson, D.M.; Ren, Z.J.; Ma, W. Brönsted catalyzed hydrolysis of microcystin-LR by siderite. Environ. Sci. Technol. 2018, 52, 6426-6437. [CrossRef] [PubMed]

13. Bae, S.; Kim, D.; Lee, W. Degradation of diclofenac by pyrite catalyzed Fenton oxidation. Appl. Catal. B Environ. 2013, 134-135, 93-102. [CrossRef]

14. Zhang, Y.; Tran, H.P.; Hussain, I.; Zhong, Y.; Huang, S. Degradation of $p$-chloroaniline by pyrite in aqueous solutions. Chem. Eng. J. 2015, 279, 396-401. [CrossRef]

15. Gil-Lozano, C.; Losa-Adams, E.; Dávila, A.F.; Gago-Duport, L. Pyrite nanoparticles as a Fenton-like reagent for in situ remediation of organic pollutants. Beilstein J. Nanotechnol. 2014, 5, 855-864. [CrossRef] [PubMed]

16. Zhang, P.; Yuan, S. Production of hydroxyl radicals from abiotic oxidation of pyrite by oxygen under circumneutral conditions in the presence of low-molecular-weight organic acids. Geochim. Cosmochim. Acta 2017, 218, 153-166. [CrossRef]

17. Wang, S.; Ma, W.; Fang, Y.; Jia, M.; Huang, Y. Bismuth oxybromide promoted detoxification of cylindrospermopsinunder UV and visible light illumination. Appl. Catal. B Environ. 2014, 150-151, 380-388. [CrossRef]

18. Wang, L.; He, D.; Chen, W.; Yu, H.Q. Probing the roles of $\mathrm{Ca}^{2+}$ and $\mathrm{Mg}^{2+}$ in humic acids-induced ultrafiltration membrane fouling using an integrated approach. Water Res. 2015, 81, 325-332. [CrossRef] [PubMed]

19. Lin, D.; Li, T.; Yang, K.; Wu, F. The relationship between humic acid (HA) adsorption on and stabilizing multiwalled carbon nanotubes (MWNTs) in water: Effects of HA, MWNT and solution properties. J. Hazard. Mater. 2012, 241-242, 404-410. [CrossRef] [PubMed]

20. Bader, H.; Sturzenegger, V.; Hoigne, J. Photometric method for the determination of low concentrations of hydrogen peroxide by the peroxidase catalyzed oxidation of N, N-diethyl-p-phenylenediamine (DPD). Water Res. 1988, 22, 1109-1115. [CrossRef]

(C) 2019 by the authors. Licensee MDPI, Basel, Switzerland. This article is an open access article distributed under the terms and conditions of the Creative Commons Attribution (CC BY) license (http://creativecommons.org/licenses/by/4.0/). 